\title{
PENGARUH PROFITABILITY, LIQUIDITY, LEVERAGE, DIVIDEND POLICY, FIRM SIZE, DAN FIRM GROWTH TERHADAP NILAI PERUSAHAAN
}

\author{
Auliya Kusuma Wardani Mahardikari \\ Universitas Negeri Surabaya \\ auliya.17080574130@mhs.unesa.ac.id
}

\begin{abstract}
Firm value is the company's goal is maximizing the present value of all future shareholder profits. Observe the effect of profitability, liquidity, leverage, dividend policy, firm size, and firm growth towards the firm value of various industrial sector companies listed on the Indonesia Stock Exchange (IDX) in 2015-2019 are the aim of this research. This type of research is explanative with a quantitative approach. Price Book Value $(P B V)$ in this research used to measure the firm value. The Sampling data used in this research is purposive sampling techniques and consisted of 12 companies of 51 companies as a population. Analysis techniques use multiple linear regression. This research gets the result that profitability, liquidity, and dividend policy have a positive significant, firm size and firm growth does not affect firm value, and then leverage has a significant negative effect on firm value.
\end{abstract}

Keywords: firm growth; firm size; leverage; liquidity, profitability

\section{PENDAHULUAN}

Kemajuan perekonomian global menimbulkan banyaknya persaingan usaha yang mana perusahaan dituntut untuk memiliki keunikan atau keunggulan dalam usahanya. Laba yang dihasilkan dapat menjadi nilai tambah suatu perusahaan. Tetapi prinsip ekonomi yang diterapkan oleh perusahaan umumnya tidak hanya sebagai pencapaian laba tertinggi, melainkan sebagai usaha untuk meningkatkan nilai perusahaan dan kemakmuran pemilik serta meningkatkan kepercayaan pasar pada tujuan di masa yang akan datang (Octaviany et al., 2019).

Tujuan suatu perusahaan adalah untuk memaksimalkan nilai perusahaan atau kekayaan bagi pemegang saham. Memaksimalkan nilai perusahaan dinilai lebih tepat sebagai tujuan suatu perusahaan sebab memaksimalkan nilai perusahaan berarti memaksimumkan nilai sekarang dari semua keuntungan yang akan diterima oleh pemegang saham di masa yang akan datang. Nilai saham perusahaan mencerminkan nilai perusahaan. Dengan kata lain, jika nilai perusahaan turun maka nilai pasar saham juga akan turun, begitu juga jika nilai perusahaan naik maka nilai pasar saham akan naik juga (Sudana, 2015).

Menurut Maryam et al. (2020), nilai perusahaan bisa dikatakan suatu tujuan perusahaan dalam konsepnya untuk memaksimalkan nilai perusahaan, dapat dengan memaksimalkan nilai yang ada sekarang dari semua pemegang saham di masa mendatang. Pengukuran nilai perusahaan dengan proksi Price to Book Value (PBV), menunjukkan sejauh mana perusahaan dapat membuat nilai perusahaan yang tidak pasti berdasarkan jumlah modal yang diinvestasikan. Perbedaan dengan penelitian terdahulu terletak pada rentang waktu. Penelitian ini menggunakan rentang tahun 20152019 dan variabel independen yang lebih banyak.

Gambar 1, terjadi pergerakan secara fluktuatif hampir semua sektor tahun 2015-2019, namun beda dengan sektor aneka industri yang mengalami pergerakan cukup stabil dan mengalami kenaikan di 2019. Nilai PBV aneka industri setiap tahunnya tidak mengalami perubahan yang cukup jauh, nilai PBV tahun 2017 sebesar 1,47 menurun tahun 2018 sebesar 1,38 dan mengalami kenaikan cukup drastis tahun 2019 sebesar 2,80. Hal tersebut membuktikan bahwa sektor aneka industri adalah sektor yang baik dalam memertahankan perolehan persentase PBV. Hasil grafik dilakukan pada berbagai perusahaan industri yang ada di Bursa Efek Indonesa tahun 2015-2019. 
Auliya Kusuma Wardani Mahardikari. Pengaruh Profitability, Liquidity, Leverage, Dividend Policy, Firm Size, dan Firm Growth terhadap Nilai Perusahaan

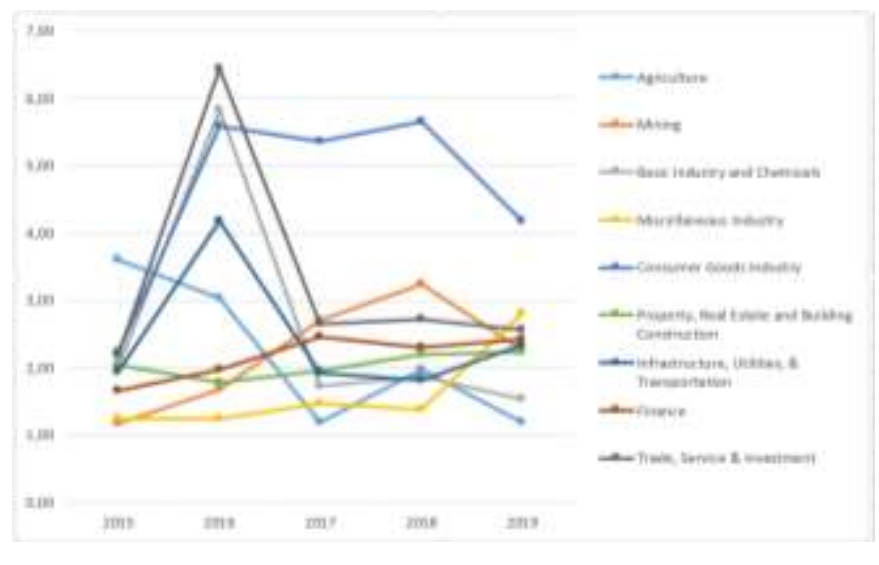

Sumber: www.idx.co.id (2020, data diolah)

Gambar 1. RATIO PBV TAHUN 2015-2019

Selama tahun 2019 kinerja IHGS tercatat melemah 0,41\% yang menjadikan hampir menduduki posisis ke dua terendah dibandingkan dengan bursa saham utama di kawasan Asia. Pelemahan yang dicatatkan oleh IHGS tentunya tisak terlepas dari pergerakan indeks-indeks sektoral. Sektor aneka industri mengalami pelemahan terdalam dengan anjlok sebesar $16,05 \%$. Sejalan dengan industri manufaktur sepanjang 2019 yang mengalami penurunan saham-saham industri otomotif dan komponennya juga melemah. Sektor aneka industri yang menaungi industri otomotif dan komponen mangalami penurunan $7,03 \%$ sejak awal tahun, seiring dengan penurunan industri manufaktur kerena permintaan akan otomotif yang menurun (cnbcindonesia.com, 2019). Maka dari itu fenomena yang dialami oleh sektor aneka industri menarik untuk dilakukan penelitian lebih lanjut.

Peningkatan nilai perusahaan dapat dipertimbangkan dengan baik sebagai bahan evaluasi maupun penentuan pengambilan keputusan untuk kepentingan perusahaan dengan beberapa faktor diantaranya adalah profitability, liquidity, leverage, dividend policy, firm size, dan firm growth. Menurut Rudangga \& Sudiarta (2016), profitabilitas akan memengaruhi skala perolehan nilai perusahaan, karena profitabilitas mampu menghasilkan keuntungan dari penjualan barang atau jasa yang dihasilkan perusahaan, sehingga profitabilitas menjadikan perusahaan sangat bernilai dan membuat investor semakin berani untuk melakukan investasi di perusahaan. Atmikasari et al. (2020), Lumoly et al., (2018), Lubis et al. (2020), Verdian \& Ispriyahadi (2020), Mayogi \& Fidiana, (2016), dengan hasil yang didapat signifikan positif pada profitabilitas terhadap nilai perusahaan. Beda dengan Siddik \& Chabachib (2015), Prasetya \& Musdholifah (2020), Hirdinis (2019), hasil tidak signifikan.

Likuiditas yaitu kegiatan perusahaan memenuhi kewajiban jangka pendeknya, jika dapat memenuhi kewajiban secara tepat waktu maka perusahaan dalam keadaan likuid. Tingginya tingkat likuiditas maka semakin tinggi pula peluang perusahaan dalam berkembang (Aslindar \& Lestari, 2020). Penelitian dari Putra \& Lestari (2016), Rudangga \& Sudiarta (2016), Maryam et al. (2020), Putra \& Sedana (2019), mendapat hasil signifikan positif hubungan likuiditas dan nilai perusahaan. Beda dengan Akbar \& Fahmi (2019), Siddik \& Chabachib (2015) yang mendapatkan hasil signifikan negatif, sedangkan Annisa \& Chabachib (2017), Dwi Artati (2020), Ndruru et al. (2020), Tantawi \& Jonnardi (2020), Verdian \& Ispriyahadi (2020), Kurniawan \& Ardiansyah, (2020), Ningsih \& Sari (2019) mendapatkan hasil yang tidak signifikan.

Leverage ialah pendanaan yang dilakukan menggunakan sebagian aset perusahaan dengan sekuritas yang menanggung beban pengembalian agar dapat meningkatkan pengembangan akhir bagi pemegang saham (Wulandari, 2013). Octaviany et al. (2019), Verdian \& Ispriyahadi (2020), Kurniawan \& Ardiansyah (2020), pengaruh leverage pada nilai perusahaan adalah signifikan positif. Sedangkan Nainggolan \& Listiadi (2014) berpengaruh signifikan negatif, dan Novari \& Lestari (2016), Ndruru et al. (2020), Mayogi \& Fidiana (2016) hasilnya tidak ada hubungan antara leverage terhadap nilai perusahaan. 
Faktor selanjutnya kebijakan deviden merupakan putusan suatu perusahaan dalam menggunakan keuntungan yang diperolehnya, keuntungan tersebut akan diinvestasikan kembali atau dibagikan sebagai dividen ke pemegang saham (Putra \& Lestari, 2016). Sugiarto (2011), Prastuti \& Sudiartha (2016), Mayogi \& Fidiana (2016), Putra \& Lestari (2016) mendapatkan hasil signifikan positif, sedangkan menurut Maryam et al. (2020), Akbar \& Fahmi (2019), Tamrin et al. (2017) tidak ada pengaruh antara variabel tersebut.

Faktor berikutnya yaitu ukuran perusahaan merupakan gambaran dari total aset yang dimiliki. Vernando \& Erawati (2020), Anjarwati et al. (2016), Artati (2020), Novari \& Lestari (2016), Hirdinis (2019) mendapatkan hasil signifikan positif dalam hubungan antara ukuran perusahaan dan nilai perusahaan. Penelitian berbeda didapat oleh Prastuti \& Sudiartha (2016), yaitu signifikan negatif dan penelitan dari Laksitaputri (2013), Azmi et al. (2018), Octaviany et al. (2019), Lumoly et al. (2018), Akbar \& Fahmi (2019), Siddik \& Chabachib (2015), mendapatkan hasil yang tidak signifikan.

Faktor terakhir yaitu pertumbuhan perusahaan. Menurut Maryam et al. (2020), perusahaan dengan pertumbuhan yang pesat memeroleh hasil positif dalam menstabilkan posisinya di era persaingan, secara signifikan penjualan ditingkatkan, dan diringi peningkatan sasaran pasar. Pengaruh positif signifikan pertumbuhan perusahaan dengan nilai perusahaan dikemukakan oleh Purwanto \& Marsono (2017), Gustian (2017), sedangkan menurut Tantawi \& Jonnardi (2020) adalah signifikan negatif, Menurut Laksitaputri (2013), Maryam et al. (2020), tidak adanya pengaruh antar kedua variabel. Oleh sebab itu penelitian ini bertujuan mengetahui pengaruh profitability, liquidity, leverage, dividend policy, firm size, dan firm growth terhadap nilai perusahaan.

\section{KAJIAN PUSTAKA DAN PENGEMBANGAN HIPOTESIS}

\section{Agency Theory}

Teori ini dipaparkan oleh Jensen \& Meckling (1976), di mana suatu hubungan keagenan dari satu atau lebih pemilik perusahaan dengan melibatkan orang lain yang berperan sebagai manajer dengan tujuan untuk melakukan tindakan atas nama pemilik untuk tujuan dalam hal kepentingan pengambilan keputusan dengan melakukan pendelegasian dari beberapa otoritas. Dalam hal ini, agen harus bertanggung jawab atas manajemen perusahaan, dan harus memberikan informasi mengenai status perusahaan. Menurut Wongso (2013), teori ini penting karena menjelaskan mengenai fungsi pengelolaan dari pemilik perusahaan dengan fungsi kepemilikan yang dilakukan oleh pemegang saham perusahaan.

\section{Signaling Theory}

Menurut Gustian (2017), signaling theory dapat diketahui seperti apa perusahaan memberi sinyal terhadap penggunaan laporan keuangan dan juga para investor yang akan melakukan investasi. Teori ini penting karena memberikan ruang untuk investor bagaimana mengetahui cara menentukan keputusan yang berkaitan dengan nilai perusahaan. Teori ini digunakan untuk menjelaskan pengaruh profitabilitas, likuiditas, dan ukuran perusahaan terhadap nilai perusahaan.

\section{Bird in the Hand Theory}

Menurut Gordon (1962) dan Lintner (1956,1963), investor yakin dengan penerimaan dan pembagian dividen dari pada hasil dari kenaikan modal oleh laba perusahaan. Saat perusahaan mampu membayar dan memberikan dividen tinggi, maka harga saham akan tinggi pula (Abdillah, 2013), teori ini digunakan untuk menjelaskan pengaruh antara kebijakan deviden dengan nilai perusahaan.

\section{Nilai Perusahaan}

Menurut Aslindar \& Lestari (2020), nilai perusahaan yaitu keberhasilan kinerja perusahaan dapat dilihat dari harga saham. Tingginya nilai perusahaan dapat membuat pasar lebih percaya terhadap pola kerja manajemen dalam mengelola perusahaan serta prospek perubahaan di masa mendatang. Price to Book Value (PBV) merupakan kemampuan perusahaan dalam menghasilkan nilai yang tidak pasti dengan modal yang telah diinvestasikan, sehingga PBV diformulasikan dengan rumus (1). 
Auliya Kusuma Wardani Mahardikari. Pengaruh Profitability, Liquidity, Leverage, Dividend Policy, Firm Size, dan Firm Growth terhadap Nilai Perusahaan

$P B V=\frac{\text { Harga Saham }}{\text { Nilai Buku Ekuitas }} \times 100 \%$

\section{Profitability}

Rasio profitability dapat menunjukkan kemampuan perolehan laba perusahaan yang diukur menggunakan seluruh dana yang diinvestasikan atau modal sendiri dari perusahaan dan ukuran efektivitas perolehan manajemen perusahaan (Wiagustini, 2010). Menurut Purwohandoko (2009:47), Return on Equity (ROE) sebagai alat ukur tingkat pembelian suatu investasi untuk para investor yang memiliki saham biasa atau pemilik modal, sehingga ROE diformulasikan dengan rumus (2).

$R O E=\frac{\text { Laba Bersih }}{\text { Modal Sendiri }} \times 100 \%$

\section{Liquidity}

Menurut Wiagustini (2010), liquidity yaitu mampu tidaknya perusahaan dalam menggunakan aset lancar untuk membayarkan kewajiban keuangan jangka pendek. Menurut Purwohandoko (2009), Current Ratio (CR) dapat digunakan untuk mengetahui sejauh mana para kreditor dapat dipenuhi tagihan jangka pendek dengan aset yang diharapkan, sehingga CR diformulasikan dengan rumus (3).

$C R=\frac{\text { Aset Lancar }}{\text { Utang Lancar }} \times 100 \%$

\section{Leverage}

Leverage merupakan kemampuan perusahaan dalam mengetahui sejauh mana perusahaan tersebut dibiayai oleh hutang (Wiagustini, 2010). Menurut Anjarwati et al. (2016), Debt to Equity Ratio (DER) menggambarkan sumber pendanan perusahaan yang membandingkan total hutang dan modal sendiri, sehingga DER diformulasikan dengan rumus (4).

DER $=\frac{\text { Total Hutang }}{\text { Modal Sendiri }} \times 100 \%$

\section{Dividend Policy}

Dividend Policy, suatu keputusan yang dilakukan perusahaan dalam membagikan laba sebagai dividen kepada pemegang saham untuk membiayai investasi di masa depan (Wiagustini, 2010). Menurut Artati (2020), membandingkan dividen tunai per saham dan laba per saham dapat menggunakan Dividend Payout Ratio (DPR), sehingga DPR diformulasikan dengan rumus (5).

$D P R=\frac{\text { Dividen Tunai per Saham }}{\text { Laba per Saham }}$

\section{Firm Size}

Menurut Rudangga \& Sudiarta (2016) firm size merupakan total aset perusahaan, dengan melihat ukuran perusahaan yang semakin besar akan lebih mudah mendapatkan sumber pendanaan. Firm Size (LN) adalah gambaran dari skala perusahaan yang dapat dilihat dari jumlah aset (Octaviany et al., 2019). Berdasarkan paper yang dijelaskan oleh Rudangga \& Sudiarta (2016), Firm size diformulasikan dengan rumus (6).

Firm Size $=(\mathrm{LN})$ Total Asset

\section{Firm Growth}

Firm Growth merupakan kemampuan perusahaan memeroleh laba setinggi-tingginya agar sahamnya diminati oleh para investor. Assets growth diukur menggunakan perubahan total aset (Gustian, 2017). Aslindar \& Lestari (2020), dalam papernya dijelaskan Assets growth diformulasikan dengan rumus (7).

Assets Growth $=\frac{\text { total aset }_{t}-\text { total aset }_{t-1}}{\text { total aset }_{t-1}} \times 100 \%$ 


\section{Pengaruh antar Variabel}

Profitability yaitu suatu bagian untuk menciptakan nilai perusahaan yang menunjukkan peluang perusahaan di masa depan (Wulandari, 2013). Hal ini sesuai dengan penjelasan signaling theory bahwa profitability akan menjadi sinyal dari pihak manajemen yang menggambarkan kemungkinan perusahaan yang menjadikan profitability untuk dasar yang membentuk dan secara langsung memengaruhi nilai perusahaan yang dilihat melalui harga saham (Anjarwati et al., 2016). Analisis profitability diproksikan dengan Return on Equity (ROE) ialah rasio yang membandingkan keuntungan bersih dengan modal perusahaan sendiri sebagai ukuran besaran pengembalian investasi untuk pemegang saham biasa atau pemilik modal (Lumoly et al., 2018).

H1 : Profitability berpengaruh terhadap nilai perusahaan pada perusahaan sektor aneka industri yang tercatat di IDX tahun 2015-2019.

Liquidity akan mendapat respon yang baik oleh pasar jika mampu memenuhi kewajiban jangka pendeknya (Tantawi \& Jonnardi, 2020). Keterkaitan antara liquidity dengan nilai perusahaan dijelaskan melalui signaling theory yaitu saat liquidity tinggi pasar akan percaya pada perusahaan, karena tingkat likuiditas dapat dijaga oleh perusahaan, yang berarti kinerja yang baik dimiliki oleh perusahaan tersebut (Wulandari, 2013). Analisis liquidity dijelaskan menggunakan proksi current ratio (CR) yang mana tinggginnya kemampuan suatu kas akan berpengaruh pada kemampuan membayar hutang jangka pendek perusahaan dan ada pengaruh positif terhadap nilai perusahaan (Mahendra et al., 2012).

$\mathrm{H} 2$ : Liquidity berpengaruh terhadap nilai perusahaan pada perusahaan sektor aneka industri yang tecatat di IDX tahun 2015-2019.

Leverage yang di mana sebuah perusahaan baik dapat mengelola hutangnya untuk pendanaan investasi dengan tingkat ukuran yang pas, maka perusahaan semakin mendapat kepercayaan dan wewenang dari para investor untuk menanamkan modalnya (Rachman \& Rahayu, 2015). Hal ini sesuai dengan penjelasan agency theory, adanya hubungan antara manajer dengan pemiliki saham. Pemegang saham memberikan wewenang kepada pihak manajemen perusahaan untuk melakukan segala sesuatu dengan keinginan pemegang saham dalam mengambil keputusan. Analisis leverage dijelaskan menggunakan proksi Debt to Equity Ratio (DER) yaitu rasio yang dapat mengukur seberapa jauh perusahaan menggunakan hutang dalam pendanaannya (Annisa \& Chabachib, 2017).

H3 : Leverage berpengaruh terhadap nilai perusahaan pada perusahaan sektor aneka industri yang tercatat di IDX tahun 2015-2019.

Dividen policy merupakan kebijakan yang berhubungan dengan hak pemegang saham dalam keputusan untuk menggunakan keuntungan, keuntungan tersebut dapat ditahan untuk diinvestasikan kembali atau dibagikan sebagai dividen (Wongso, 2013). Pada dasarnya semua investor mencari keuntungan dalam berinvestasi di mana kebijakan dividen ini merupakan kegiatan dalam membagikan keuntungannya jika dividen tinggi menjadi sinyal yang baik bagi para investor, dalam hal ini keterkaitan dividend policy dengan nilai perusahaan sesuai dengan penjelasan bird in the hand theory yaitu apabilia dividen yang dibagikan tinggi maka nilai perusahaan juga akan tinggi (Rahayu, 2014). Analisis dividend policy diukur menggunakan Dividend Payout Ratio (DPR) di mana tingginya nilai DPR akan memengaruhi nilai perusahaan menjadi semakin tinggi (Himawan \& Christiawan, 2016)

H4 : Dividen policy berpengaruh terhadap nilai perusahaan pada perusahaan sektor aneka industri yang tercatat di IDX tahun 2015-2019.

Firm size dapat memberikan informasi seberapa besar kegiatan yang ada pada perusahaan, umumnya juka ukuran perusahaan besar, maka besar pula aktivitasnya. Dapat diartikan semakin meningkat ukuran perusahaan, semakin meningkat pula nilai perusahaan, hal tersebut sesuai dengan konsep signaling theory yang menjadi sinyal bahwa perusahaan dengan ukuran besar akan memiliki prospek 
Auliya Kusuma Wardani Mahardikari. Pengaruh Profitability, Liquidity, Leverage, Dividend Policy, Firm Size, dan Firm Growth terhadap Nilai Perusahaan

yang baik di masa yang akan datang dan akan berpengaruh terhadap nilai perusahaan (Anjarwati et al., 2016). Analisis ini menggunakan log total aset sebagai alat ukur dari firm size.

H5 : Firm size berpengaruh terhadap nilai perusahaan pada perusahaan sektor aneka industri yang tercatat di IDX tahun 2015-2019.

Firm growth ialah kemampuan perusahaan untuk memeroleh laba tinggi yang mencerminkan baiknya nilai perusahaan, sehingga akan lebih tinggi return yang diharapkan serta akan menambah kepercayaan bagi para investor (Gustian, 2017). Agency theory memerlihatkan hubungan antara pertumbuhan perusahaan terhadap nilai perusahaan di mana aset suatu perusahaan digunakan untuk kegiatan operasional perusahaan sehingga menambah kepercayaan serta dapat memberikan sinyal positif bagi pihak luar maupun pihak dalam perusahaan (Suryandani, 2018). Pertumbuhan perusahaan diukur menggunakan perubahan total aset.

H6: Firm Growth berpengaruh terhadap nilai perusahaan pada perusahaan sektor aneka industri yang tercatat di IDX tahun 2015-2019.

\section{METODE PENELITIAN}

Data penelitian menggunakan data kuantitatif berupa data sekunder yang diperoleh dari laman Bursa Efek Indonesia dan laman masing-masing perusahaan. Penelitian ini memiliki enam variabel independen, yaitu profitability, liquidity, leverage, devidend policy, firm size, dan firm growth, sedangkan PBV (Price to Book Value) merupakan variabel dependen. Perusahaan aneka industri yang tercatat di Bursa Efek Indonesai tahun 2015-2019 menjadi populasi dalam penelitian ini. Purposive sampling dipilih sebagai metode pengambilan sampel dengan kriteria perusahaan menerbitkan annual report, perusahaan dalam kondisi laba, dan perusahaan menerbitkan kebijakan dividen secara terus menerus pada tahun 2015-2019. Jumlah sampel yang memenuhi kriteria sebanyak 12 perusahaan. Penggunaan uji asumsi klasik untuk teknik analisis data ialah uji normalitas, uji multikolonieritas, uji autokorelasi, dan uji heterokedastisitas. Berikutnya pengujian hipotesis meliputi uji determinasi $\mathrm{R}^{2}$, uji statistik F, uji statistik t, dan uji regresi linier berganda.

\section{HASIL DAN PEMBAHASAN}

\section{Uji Asumsi Klasik}

Berdasarkan tabel 1, variabel SQRT_PBV, Sqrt_ROE, Sqrt_DPR, Sqrt_GROWTH mempunyai nilai Asymp. Sig. (2-tailed) 0,200>0,05 yang artinya data berdistribusi normal. Kemudian untuk nilai dari variabel Sqrt_CR, Sqrt_DER, Sqrt_SIZE tetap tidak mengalami perubahan yang artinya tidak berdistribusi dengan normal, sehingga variabel tersebut dapat dipertahankan atau dihilangkan. Pada penelitian ini variabel; CR, DER, SIZE tetap dipertahankan. Model variabel yang digunakan untuk melakukan uji statistik yaitu Sqrt_PBV, Sqrt_ROE, CR, DER, Sqrt_DPR, SIZE, dan Sqrt_GROWTH.

\section{Tabel 1. \\ HASIL TRANSFORMASI DATA}

\begin{tabular}{lcccccccc}
\hline & & $\begin{array}{c}\text { SQRT } \\
\text { PBV }\end{array}$ & $\begin{array}{c}\text { SQRT } \\
\text { _ROE }\end{array}$ & $\begin{array}{c}\text { SQRT } \\
\text { _CR }\end{array}$ & $\begin{array}{c}\text { SQRT } \\
\text { _DER }\end{array}$ & $\begin{array}{c}\text { SQRT } \\
\text { _DPR }\end{array}$ & $\begin{array}{c}\text { SQRT } \\
\text { _SIZE }\end{array}$ & $\begin{array}{c}\text { SQRT_G } \\
\text { ROWTH }\end{array}$ \\
\hline $\mathrm{N}$ & & 47 & 47 & 47 & 47 & 47 & 47 & 47 \\
Normal Parameters & Mean & 1.078 & 3.172 & 10.649 & 5.386 & 5.019 & 3.489 & 2.748 \\
& SD & .452 & 1.368 & 8.603 & 4.442 & 1.903 & .537 & 1.273 \\
Asymp. Sig. (2-tailed) & & .200 & .200 & .000 & .000 & .200 & .000 & .200 \\
\hline
\end{tabular}

Sumber: Output SPSS (2021, data diolah)

Tabel 2, diketahui pengujian normalitas dengan metode Kolmogorov-Smirnov mendapat hasil signifikansi 0,200 >0,05, hal tersebut menjelaskan data berdistribusi normal. Berikutnya, uji autokorelasi run test dengan hasil signifikansi 1,000 > 0,005 yang artinya autokorelasi pada data tidak 
terjadi. Hasil dari pengujian multikolonieritas mendapat hasil bahwa semua variabel independen mendapat nilai $>0,1$ dan nilai VIF $<10$, maka tidak terdapat multikolonieritas. Kemudian pengujian terakhir adalah uji heterokedastisitas dengan hasil semua variabel independen memiliki signifikansi > 0,05 dengan menggunakan uji spearman, yang berarti tidak memiliki gejala heterokedastisitas.

Tabel 2.

HASIL UJI ASUMSI KLASIK

\begin{tabular}{lccccc}
\hline \multicolumn{1}{c}{ Variabel } & Normalitas & Autokorelasi & \multicolumn{2}{c}{ Multikolonieritas } & Heterokedastisitas \\
& Sig. & Run Test & Tolerance & VIF & Sig. \\
\hline (Constant) & .200 & 1.000 & & & \\
Sqrt_ROE & & & .768 & 1.302 & .778 \\
CR & & & .280 & 3.574 & .958 \\
DER & & & .283 & 2.536 & .624 \\
Sqrt_DPR & & & .703 & 1.442 & .851 \\
SIZE & & & .597 & 1.675 & .324 \\
Sqrt_GROWTH & & & .766 & 1.306 & .787 \\
\hline
\end{tabular}

Sumber: Output SPSS (2021, data diolah)

\section{Uji determinasi $\left(\mathbf{R}^{2}\right)$}

Tabel 3, hasil uji determinasi $\left(\mathrm{R}^{2}\right)$ sebesar 0.643 atau 64,3\%. Artinya kemampuan model variabel dependen dapat dijelaskan melalui variabel independen yang meliputi profitability, liquidity, leverage, dividend policy, firm size, dan firm growth sebesar 64,3\%, sedangkan untuk sisanya 35,7\% dipengaruhi variable lain di luar model.

\section{Uji Hipotesis}

Hasil uji F, signifikansi sebesar 0,000 $<0,005$ jadi profitability, liquidity, leverage, dividend policy, firm size, firm growth berpengaruh secara simultan terhadap nilai perusahaan. Hasil uji regresi linier berganda diperoleh model persamaan (8).

$\mathrm{PBV}=0,016+0,210 \mathrm{ROE}+0,001 \mathrm{CR}-0,004 \mathrm{DER}+0,64 \mathrm{DPR}+\mathrm{e}$

Hasil uji t menunjukkan bahwa hasil profitability berpengaruh terhadap PBV karena thitung 6,331 > t tabel 2,021 dan memiliki signifikansi 0,000 atau $<0,05$. Liquidity berpengaruh terhadap PBV karena t hitung 2,603 > t tabel 2,021 dan memiliki signifikansi 0,013 atau $<0,05$. Leverage berpengaruh negatif terhadap PBV karena t hitung -2,542 > t tabel 2,021 dan memiliki signifikansi 0,015 atau < 0,05. Dividend policy berpengaruh terhadap PBV karena t hitung 2,544 >t tabel 2,021 dan memiliki signifikansi 0,015 atau $<0,05$. Firm size tidak berpengaruh terhadap PBV karena t hitung $0,014<\mathrm{t}$ tabel 2,021 dan memiliki signifikansi 0,989 atau $>0,05$. Firm growth tidak berpengaruh terhadap PBV karena t hitung 0,545 < t tabel 2,021 dan memiliki signifikansi 0,588 atau >0,05.

Tabel 3.

\section{HASIL UJI HIPOTESIS}

\begin{tabular}{lcccccc}
\hline \multicolumn{1}{c}{ Variabel } & $\begin{array}{c}\text { Determinasi R } \\
\text { Adj. Rsquare }\end{array}$ & Sig. & Uji F & Coefficient & \multicolumn{2}{c}{ Uji T } \\
& .643 & .000 & 14.799 & & t & Sig. \\
\hline (Constant) & & & & .016 & .060 & .952 \\
Sqrt_ROE & & & & .210 & 6.331 & .000 \\
CR & & & & .001 & 2.603 & .013 \\
DER & & & & -.004 & -2.542 & .015 \\
Sqrt_DPR & & & .064 & 2.544 & .015 \\
SIZE & & & .000 & .014 & .989 \\
Sqrt_GROWTH & & & & .020 & .545 & .588 \\
\hline Sumber: Output SPSS (2021, data diolah) & & & & & & \\
\end{tabular}


Auliya Kusuma Wardani Mahardikari. Pengaruh Profitability, Liquidity, Leverage, Dividend Policy, Firm Size, dan Firm Growth terhadap Nilai Perusahaan

\section{Pengaruh Profitability terhadap PBV}

Analisis data diperoleh profitabilitas berpengaruh pada nilai perusahaan. Temuan tersebut sejalan dengan signaling theory, bahwa profitabilitas akan jadi sinyal yang baik dilihat dari laba yang dihasilkan, jika laba tinggi maka kesempatan perusahaan dalam merencanakan kegiatan di masa mendatang akan tinggi maka nilai perusahaan yang dilihat dari saham perusahaan akan meningkat. Dengan hal tersebut maka kepercayaan investor akan meningkat pula (Anjarwati et al., 2016). Adanya pengaruh dari profitabiliby terhadap nilai perusahaan karena pemegang saham akan mendapat pengembalian investasi yang tinggi, jika perusahaan dapat mengelola laba dengan baik. Sejalan dengan Lubis et al. (2020) tingginya tingkat pengembalian tersebut akan menjadi pemicu investor untuk membeli saham perusahaan tersebut dan permintaan saham yang meningkat akan memengaruhi secara langsung dalam meningkatnya nilai perusahaan. Penelitian ini didukung oleh Atmikasari et al. (2020), Rudangga \& Sudiarta (2016), Rudangga \& Sudiarta, (2016), Lumoly et al. (2018), Maryam et al. (2020), Verdian \& Ispriyahadi (2020), dan Mayogi \& Fidiana (2016). Data dari KMI Wire and Cable Tbk dan Supreme Cable Manufacturing \& Commerce Tbk dengan PBV 1,47 tahun 2017 menurun 1,38 pada tahun 2018 dan mengalami kenaikan sebesar 2,80 tahun 2019, maka sejalan dengan nilai ROE yang ada di perusahaan tersebut. Implikasi dari peneilitian ini adalah profitability (ROE) berpengaruh terhadap nilai perusahaan (PBV). Setiap kenaikan dan penurunan nilai profitability (ROE) akan memengaruhi nilai perusahaan (PBV). Perusahaan dapat menggunakan profitabilitas sebagai prospek yang baik di masa mendatang, artinya kemampuan perusahaan akan dinilai baik oleh investor. Jika perusahaan mampu melakukan peningkatan laba dengan baik, maka harga saham akan meningkat.

\section{Pengaruh Liquidity terhadap PBV}

Berdasarkan analisis data, liquidity berpengaruh terhadap nilai perusahaan. Sejalan dengan signaling theory yang mana perusahaan mampu memberikan informasi yang positif kepada para investor mengenai bagaimana perusahaan dalam membayar hutang jangka pendek yang dapat direspon positif oleh pasar. Hal ini bisa terjadi karena kemampuan kas perusahaan dalam menggunakan aset lancar dengan baik untuk membayar hutang jangka pendek. Maka, perusahaan tersebut dapat mengelola keuangan dengan sebaik mungkin (Mahendra et al., 2012). Hasil penelitian ini konsisten dengan penelitian Putra \& Lestari (2016), likuiditas memiliki peranan penting dalam kesuksesan perusahaan. Tingkat likuiditas dari sebuah perusahaan yang baik akan dianggap oleh investor nilai perusahaannya juga baik, maka para investor akan tertarik untuk menanamkan modal mereka. Penelitian ini didukung oleh Rudangga \& Sudiarta (2016), Maryam et al. (2020), dan Putra \& Sedana (2019). Berdasarkan data dari pada PT Indo Kordsa Tbk dan PT Sri Rejeki Isman Tbk yang memiliki nilai PBV 1,47 pada tahun 2017 menurun 1,38 pada tahun 2018 dan mengalami kenaikan sebesar 2,80 tahun 2019, maka sejalan dengan nilai CR yang ada di perusahaan tersebut. Implikasi dari penelitian ini, liquidity (CR) berpengaruh terhadap nilai perusahaan (PBV). Setiap kenaikan dan penurunan nilai liquidity (CR) akan memengaruhi nilai perusahaan (PBV). Perusahaan dapat menggunakan liquidity sebagai acuan menentukan strategi investasi karena liquidity merupakan faktor yang menentukan bahwa perusahaan tersebut sehat atau tidak.

\section{Pengaruh Leverage terhadap PBV}

Leverage berpengaruh negatif terhadap nilai perusahaan. Hal ini selaras dengan agency theory yang menyatakan adanya hubungan antara manajer dengan pemiliki saham. Pemegang saham memberikan wewenang kepada pihak manajemen perusahaan untuk melakukan segala sesuatu dengan keinginan pemegang saham dalam mengambil keputusan. Peningkatan hutang akan timbul sinyal positif di mana perusahaan tersebut mendapat pencapaian yang baik, perusahaan pada sektor industri ini berskala besar dan memiliki kinerja yang baik sehingga dapat memengaruhi nilai perusahaan. Dari pihak peminjam juga akan meminjamkan kepada perusahaan yang sanggup melunasi kewajibannya. Maka pandangan positif terhadap perusahaan akan memicu peningkatan nilai perusahaan, namun jika kondisi perusahaan dalam keadaan yang kurang baik maka penggunaan hutang akan lebih rendah dibandingkan dengan biaya bunganya hal tersebut akan merugikan perusahaan (Tantawi \& Jonnardi, 2020). Hasil penelitian ini sejalan dengan Nainggolan \& Listiadi (2014) yang menyatakan hasil negatif signifikan karena hutang salah satu sumber pembiayaan yang terdapat resiko tinggi yaitu pembayaran bunga yang pada umumnya tidak dapat ditutupi oleh perusahaan. Namun hal ini 
bertentangan dengan penelitian terdahulu oleh Novari \& Lestari (2016), Ndruru et al. (2020), dan Mayogi \& Fidiana (2016). Berdasarkan data dari pada PT Sumi Indo Kabel Tbk dan Kabelindo Murni Tbk yang memiliki nilai PBV 1,47 pada tahun 2017 menurun 1,38 pada tahun 2018 dan mengalami kenaikan sebesar 2,80 tahun 2019, maka tidak berbanding lurus dengan nilai DER yang ada di perusahaan tersebut. Implikasi untuk penelitian ini adalah leverage (DER) berpengaruh negatif terhadap nilai perusahaan (PBV). Dapat diartikan bahwa setiap kenaikan atau penurunan leverage akan diiringi perubahan secara nyata oleh nilai perusahaan yang mana perubahan tersebut berbanding terbalik. Maka perusahaan akan mengalami keuntungan apabila leverage semakin menurun.

\section{Pengaruh Dividend Policy terhadap PBV}

Berdasarkan analisis data yang telah dilakukan, dividend policy memiliki pengaruh pada nilai perusahaan. Hal ini sejalan dengan bird in the hand theory, apabila deviden yang dibagikan tinggi maka nilai perusahaan juga meningkat (Rahayu, 2014). Karena pada saat harga saham meningkat, maka perusahaan akan mengumumkan naiknya dividen, lalu jika harga saham menurun maka perusahaan akan mengumumkan penurunannya. Hal ini dapat terjadi karena pemegang saham akan mendapatkan dividen dengan di bagikannya laba bersih perusahaan. Keputusan perusahaan dalam membagikan labanya jika dividen tinggi merupakan sinyal yang positif bagi investor. Investor akan lebih memilih menanamkan dananya diperusahaan tersebut sehingga membuat nilai perusahaan meningkat begitu pula dengan harga saham. Penelitian ini sejalan dengan Sugiarto (2011), Putra \& Lestari (2016), Prastuti \& Sudiartha (2016), dan (Mayogi \& Fidiana, 2016). Berdasarkan data dari pada PT Pan Brothers Tbk dan PT Sri Rejeki Isman Tbk yang memiliki nilai PBV 1,47 pada tahun 2017 menurun 1,38 pada tahun 2018 dan mengalami kenaikan sebesar 2,80 tahun 2019, maka sejalan dengan nilai DPR yang ada di perusahaan tersebut. Implikasinya adalah Dividend Policy (DPR) berpengaruh terhadap nilai perusahaan (PBV). Setiap kenaikan dan penurunan nilai Dividend Policy (DPR) akan memengaruhi nilai perusahaan (PBV). Dividend policy dapat digunakan perusahaan untuk memberikan sinyal yang positif terhadap pemegang saham, selain itu juga nilai perusahaan dapat meningkat.

\section{Pengaruh Firm Size terhadap PBV}

Firm size tidak pengaruh terhadap nilai perusahaan. Hasil ini tidak selaras dengan signaling theory, yaitu perusahaan dengan ukuran besar dapat memepengaruhi nilai perusahaan dengan memiliki prospek yang baik di masa depan (Anjarwati et al., 2016). Hal ini dapat terjadi karena besar kecilnya ukuran suatu perusahaan atas jumlah aset yang dimiliki perusahaan tidak mampu berjalan semestinya dalam upaya untuk meningkatkan profit, sehingga dikatakan tidak mampu untuk memengaruhi nilai perusahaan, dengan ukuran perusahaan yang besar belum pasti dapat mencerminkan perolehan nilai perusahaan yang baik. Hasil penelitian ini konsisten dengan Laksitaputri (2013), yaitu firm size tidak berpengaruh terhadap nilai perusahaan, dan juga didukung oleh Octaviany et al. (2019), Lumoly et al. (2018), Akbar \& Fahmi (2019), dan Siddik \& Chabachib (2015). Berdasarkan data dari pada PT Sumi Indo Kabel Tbk dan Kabelindo Murni Tbk yang memiliki nilai PBV 1,47 pada tahun 2017 menurun 1,38 pada tahun 2018 dan mengalami kenaikan sebesar 2,80 tahun 2019, maka tidak sejalan dengan nilai SIZE yang ada di perusahaan tersebut. Implikasi untuk penelitian ini firm size (SIZE) tidak dapat memengaruh nilai perusahaan (PBV). Setiap kenaikan dan penurunan nilai firm size (SIZE) tidak akan memengaruhi nilai perusahaan (PBV). Maka, perusahaan tidak dapat menggukan ukuran perusahaan atau besarnya suatu aset yang dimiliki untuk digunankan sebagai acuan dalam berinvestasi.

\section{Pengaruh Firm Growth terhadap PBV}

Berdasarkan analisis data yang dilakukan bahwa firm growth tidak adanya pengaruh pada nilai perusahaan. Hasil tersebut tidak selaras dengan agency theory yang menyatakan bahwa adanya hubungan baik investor dengan manajer dalam hal ketepatan dalam memilih aset dalam kegiatan operasional perusahaan akan memengaruhi pertumbuhan perusahaan dan meningkatkan kepercayaan investor untuk menanamkan modalnya (Tantawi \& Jonnardi, 2020). Hal ini bisa terjadi karena perusahaan tidak mampu menjaga posisi keuangan dalam era pertumbuhan ekonomi seperti ini. Perusahaan akan mengalami pertumbuhan jika jumlah asetnya meningkat. Dalam peningkatan aset dapat menunjukkan peluang adanya kemungkinan untuk perusahaan mendapat keuntungan di masa 
Auliya Kusuma Wardani Mahardikari. Pengaruh Profitability, Liquidity, Leverage, Dividend Policy, Firm Size, dan Firm Growth terhadap Nilai Perusahaan

depan, tetapi jika aset tidak menunjukkan peluang peningkatan maka tidak akan ada kemungkinan untuk mendapat keuntungan di masa mendatang. Dan investor pun akan menilai jika tidak ada peningkatan aset yang dimiliki perusahaan maka perusahaan tersebut tidak memiliki prospek yang baik. Penelitian sejalan dengan Laksitaputri (2013), Maryam et al. (2020). Berdasarkan data dari pada PT Indo Kordsa Tbk dan PT Sepatu bata Tbk dengan PBV 1,47 pada tahun 2017 menurun 1,38 pada tahun 2018 dan mengalami kenaikan sebesar 2,80 tahun 2019, maka tidak sejalan dengan nilai GROWTH yang ada di perusahaan tersebut. Maka, implikasinya adalah firm growth (GROWTH) tidak berpengaruh terhadap nilai perusahaan (PBV). Setiap kenaikan dan penurunan nilai firm growth (GROWTH) tidak akan memengaruhi nilai perusahaan (PBV). Maka peningkatan dan penurunan suatu aset tidak dapat digunakan perusahaan untuk memberikan sinyal kepada investor agar melakukan investasi.

\section{KESIMPULAN}

Profitability berpengaruh terhadap nilai perusahaan. Pengeloaan laba yang baik dan tingginya pengembalian investasi akan memengaruhi meningkatnya nilai perusahaan. Liquidity berpengaruh terhadap nilai perusahaan. Pemenuhan hutang jangka pendek yang menggunakan aset lancar berjalan dengan baik. Leverage berpengaruh negatif terhadap nilai perusahaan. Leverage dapat memberikan resiko tinggi ketika perusahaan tidak dapat membayar bunga hutang. Dividend policy berpengaruh terhadap nilai perusahaan. Keputusan perusahaan membagikan labanya sebagai dividen yang tinggi maka akan menjadi sinyal postif bagi investor yang akan menanamkan dananya yang dapat membuat harga saham dan nilai perusahaan meningkat. Keputusan perusahaan Firm Size tidak adanya pengaruh pada nilai perusahaan. Perusahaan dengan ukuran yang besar belom pasti dapat mencerminkan perolehan nilai perusahaan yang baik. Firm Growth tidak memiliki pengaruh terhdap nilai perusahaan. Perusahaan tidak mampu menjaga posisi keuangan dalam era pertumbuhan ekonomi seperti saat ini.

Keterbatasan penelitian ini berdasarkan nilai Adjusted $\mathrm{R}^{2}$ sebesar 64,3\% sedangkan 35,7\% merupakan variabel diluar model yang dapat dijelaskan pengaruhnya terhadap nilai perusahaan. Bagi penelitian selanjutnya dapat mengunakan variabel Struktur modal (Prastuti \& Sudiartha, 2016), Corporate Sosial Responsibility (CSR), Good Corporate Governance (GCG) (Khasanah \& Sucipto, 2020).

\section{DAFTAR PUSTAKA}

Abdillah, A. (2013). Analisis Pengaruh Kebijakan Dividen, Kebijakan Hutang, Profitabilitas dan Keputusan Investasi terhadap Nilai Perusahaan Manufaktur di BEI 2009-2012. Jurnal Ilmiah Manajemen, 15(7), 251-256. https://doi.org/10.1016/0165-9936(96)00040-4

Akbar, F., \& Fahmi, I. (2019). Pengaruh Ukuran Perusahaan, Profitabilitas dan Likuiditas terhadap Kebijakan Dividen dan Nilai Perusahaan pada Perusahaan Manufaktur yang Terdaftar di Bursa Efek Indonesia. Jurnal Ilmiah Mahasiswa Ekonomi Manajemen, 5(1), 62-81.

Anjarwati, K., Chabachib, M., \& Demi, I. R. (2016). Pengaruh Profitabilitas, Size, dan Likuiditas terhadap Nilai Perusahaan Manufaktur di Indonesia dengan Struktur Modal sebagai Variabel Intervening. Diponegoro Journal of Finance, 6(2), 1-20.

Annisa, R., \& Chabachib, M. (2017). Analisis Pengaruh Current Ratio (CR), Debt to Equity Ratio (DER), Return on Assets (ROA) terhadap Price To Book Value (PBV), dengan Dividend Payout Ratio sebagai Variabel Intervening (Studi Kasus pada Perusahaan Industri Manufaktur yang Terdaftar di BEI P. Diponegoro Journal of Management, 6(1), 1-15.

Artati, D. (2020). Pengaruh Return on Assets , Size dan Current Ratio terhadap Nilai Perusahaan Melalui. Jurnal Bisnis, Manajemen, dan Akuntansi, VII(1), 111-131. http://jurnal.amaypk.ac.id/index.php/jbma/article/view/92/105 
Aslindar, D. A., \& Lestari, U. P. (2020). Pengaruh Profitabilitas, Likuiditas dan Peluang Pertumbuhan terhadap Nilai Perusahaan dengan Struktur Modal sebagai Variabel Intervening. Journal of Chemical Information and Modeling, 110(9), 1689-1699.

Atmikasari, D., Indarti, I., \& Muncaraditya, E. (2020). Pengaruh Profitabilitas terhadap Nilai Perusahaan dengan Kebijakan Deviden sebagai Variabel Intervening. Jurnal Akuntansi, 1(1), 1-23. https://doi.org/10.37470/1.022.1.04

Azmi, N., Isnurhadi, I., \& Hamdan, U. (2018). Pengaruh Profitabilitas, Ukuran Perusahaan terhadap Nilai Perusahaan dengan Struktur Modal sebagai Variabel Intervening pada Perusahaan Manufaktur yang Terdaftar di Bei. Jembatan, 15(2), 95-108. https://doi.org/10.29259/jmbt.v15i2.6657

Gustian, D. (2017). Pengaruh Pertumbuhan Perusahaan, Keputusan Investasi, dan Keputusan Pendanaan terhadap Nilai Perusahaan. Jurnal Akuntansi, 5(2), 2635-5315.

Himawan, M. R., \& Christiawan, Y. J. (2016). Pengaruh Keputusan Pendanaan dan Kebijakan Dividen terhadap Nilai Perusahaan pada Sektor Manufaktur di Indonesia. Business Accounting Review, 4(1), 193-204.

Hirdinis, M. (2019). Capital Structure and Firm Size on Firm Value Moderated by Profitability. International Journal of Economics and Business Administration, 7(1), 174-191. https://doi.org/10.35808/ijeba/204

Jensen, M. C., \& Meckling, W. H. (2019). Theory of The Firm: Managerial Behavior Agency Costs and Ownership Structure. Human Relations, 72(10), 1671-1696. https://doi.org/10.1177/0018726718812602

Khasanah, I. D., \& Sucipto, A. (2020). Pengaruh Corporate Social Responbility (csr) dan Good Corporate Governance (gcg) terhadap Nilai Perusahaan dengan Profitabilitas sebagai Variabel Intervening. AKUNTABEL: Jurnal Akuntansi dan Keuangan, 17(1), 14-28.

Kurniawan, G. G., \& Ardiansyah. (2020). Pengaruh Profitabilitas, Ukuran Perusahaan, Leverage dan Likuiditas terhadap Nilai Perusahaan. Jurnal Multiparadigma Akuntansi Tarumanagara, 2(1), 367-375.

Laksitaputri, Iriena Maharani. (2013). Analisis faktor-faktor yang Mempengaruhi Nilai Perusahaan dengan Profitabilitas sebagai Variabel Intervening. E-Jurnal Akuntansi, 30(7), 18-57.

Lubis, M., Savitri, E., \& Riau, U. (2020). Analisis Pengaruh Nila Tukar Rupiah dan Bi Rate terhadap Return Saham Subsektor Perkebunan dengan Harga Referensi Crude Palm Oil (Cpo) Sebagai Variabel Moerasi. Jurnal Ilmiah Manajemen, 8(1), 108-124.

Lumoly, S., Murni, S., \& Untu, V. N. (2018). Pengaruh Likuiditas, Ukuran Perusahaan dan Profitabilitas terhadap Nilai Perusahaan (Studi pada Perusahaan Logam dan Sejenisnya yang Terdaftar di Bursa Efek Indonesia). Jurnal EMBA: Jurnal Riset Ekonomi, Manajemen, Bisnis Dan Akuntansi, 6(3), 1108-1117. https://doi.org/10.35794/emba.v6i3.20072

Mahendra, A., Artini, L. G. S., \& Suarjaya, A. . G. (2012). Pengaruh Kinerja Keuangan terhadap Nilai Perusahaan pada Perusahaan Manufaktur yang Terdaftar di Bursa Efek Indonesia. Jurnal Manajemen, Strategi Bisnis, dan Kewirausahaan, 6(2), 130-138. https://doi.org/10.37751/parameter.v4i1.31

Maryam, S., Mus, A. R., \& Priliyadi, A. (2020). Pengaruh Ukuran Perusahaan, Pertumbuhan Perusahaan, Likuiditas, Profitabilitas dan Kebijakan Dividen terhadap Nilai Perusahaan. Center 
Auliya Kusuma Wardani Mahardikari. Pengaruh Profitability, Liquidity, Leverage, Dividend Policy, Firm Size, dan Firm Growth terhadap Nilai Perusahaan

of Economic Student Journal, 3(1), 90-109.

Mayogi, D. G., \& Fidiana. (2016). Pengaruh Profitabilitas, Kebijakan Dividen, dan Kebijakan Utang terhadap Nilai Perusahaan. Jurnal Ilmu dan Riset Akuntansi, 5(1), 71-81. https://doi.org/10.21776/ub.profit.2020.014.02.9

Nainggolan, S. D. A., \& Listiadi, A. (2014). Pengaruh Kebijakan Hutang terhadap Nilai Perusahaan dengan Kebijakan Dividen sebagai Variabel Moderasi. Jurnal Ilmu Manajemen, 2(3), 868-879. https://ejournal.unesa.ac.id/index.php/jim/article/view/10177

Ndruru, M., Silaban, P. B., Sihaloho, J., Manurung, K. M., \& Sipahutar, T. T. U. (2020). Pengaruh Likuiditas, Leverage, dan Profitabilitas terhadap Nilai Perusahaan pada Perusahaan Manufaktur Tahun 2015-2017. Jurnal Ilmiah MEA (Manajemen, Ekonomi, dan Akuntansi), 4(3), 390-405.

Ningsih, S., \& Sari, S. P. (2019). Analysis of the Effect of Liquidity Ratios, Solvability Ratios and Profitability Ratios on Firm Value in Go Public Companies in the Automotive and Component Sectors. International Journal of Economics, Business and Accounting Research (IJEBAR), 3(4), 351-359.

Novari, P. M., \& Lestari, P. V. (2016). Pengaruh Ukuran Perusahaan, Leverage, dan Profitabilitas terhadap Nilai Perusahaan pada Sektor Properti dan Real Estate. E-Jurnal Manajemen Universitas Udayana, 5(9), 5671-5694.

Octaviany, A., Hidayat, S., \& Miftahudin, M. (2019). Pengaruh Ukuran Perusahaan dan Leverage terhadap Nilai Perusahaan dengan Profitabilitas sebagai Variabel Intervening. Jurnal Riset Inspirasi Manajemen dan Kewirausahaan, 3(1), 30-36. https://doi.org/10.35130/jrimk.v3i1.48

Prasetya, A. W., \& Musdholifah. (2020). Pengaruh Likuiditas Profitabilitas dan Leverage Terhadap Nilai Perusahaan yang Dimoderasi Oleh Kebijakan Dividen. Jurnal Ilmu Manajemen (JIM), $8(4)$.

Prastuti, N. K. R., \& Sudiartha, i G. M. (2016). Pengaruh Struktur Modal, Kebijakan Dividen, Dan Ukuran Perusahaan terhadap Nilai Perusahaan pada Perusahaan Manufaktur. Jurnal Manajemen Unud, 5(3), 1572-1598.

Purwanto, D., \& Marsono, A. D. (2017). Pengaruh Struktur Modal dan Pertumbuhan Perusahaan terhadap Nilai Perusahaan dengan Kinerja Perusahaan sebagai Variabel Intervening (Studi Empiris pada Perusahaan Lq 45 di Bursa Efek Indonesia Periode 2011 - 2015). Jurnal Riset Perbankan Manajemen, 1(2), 10-17.

Purwohandoko. (2009). Dasar - Dasar Manajemen Keuangan (Teori, Aplikasi dan kasus). Surabaya: Unesa University Press.

Putra, A. N. dharma A., \& Lestari, P. V. (2016). Pengaruh Profitabilitas, Likuiditas, dan Ukuran Perusahaan terhadap Nilai Perusahaan. E-Jurnal Manajemen Universitas Udayana, 8(5), 3275. https://doi.org/10.24843/ejmunud.2019.v08.i05.p25

Putra, I. G. W. R., \& Sedana, I. B. P. (2019). Capital Structure as a Mediation Variable: Profitability and Liquidity on Company Value in Real Estate Companies in Indonesia Stock Exchange. International Research Journal of Management, IT and Social Sciences, 6(4), 62-72. https://doi.org/10.21744/irjmis.v6n4.640

Rachman, A. N., \& Rahayu, S. M. (2015). Pengaruh Good Corporate dan Financial Leverage Terhadap Kinerja Keuangan dan Nilai Perusahaan (Studi pada Perusahaan yang Terdaftar di Indeks Sri Kehati Selama 2011-2014). Jurnal Administrasi Bisnis, 27(1), 1-10. 
Rahayu, F. D. (2014). Pengaruh Ukuran Perusahaan, Leverage, Profitabilitas, Kebijakan Dividen dan Cash Holding terhadap Nilai Perusahaan pada Sektor Manufaktur. Jurnal Ilmu Manajemen (JIM), 2(2).

Rudangga, I. G. N. G., \& Sudiarta, G. M. (2016). Pengaruh Pertumbuhan Perusahaan dan Leverage terhadap Profitabilitas dan Nilai Perusahaan. E-Jurnal Manajemen Universitas Udayana, 3(5), 4394-4422.

Siddik, M. H., \& Chabachib, M. (2015). Pengaruh Roe, Cr, Size, dan Kepemilikan Institusional terhadap Nilai Perusahaan dengan Struktur Modal sebagai Variabel Intervening. Diponegoro Journal of Management, 6(4), 1-15. http://ejournal-s1.undip.ac.id/index.php/dbr

Sudana, I. M. (2015). Manajemen Keuangan Perusahaan (Tujuan perusahaan). Jakarta: Penerbit Erlangga.

Sugiarto, M. (2011). Pengaruh Struktur Kepemilikan dan Kebijakan Dividen terhadap Nilai Perusahaan dengan Kebijakan Hutang sebagai Intervening. Jurnal Akuntansi Kontemporer, 3(1), 243887. https://doi.org/10.33508/jako.v3i1.1012

Suryandani, A. (2018). Pengaruh Pertumbuhan Perusahaan, Ukuran Perusahaan, dan Keputusan Investasi terhadap Nilai Perusahaan pada Perusahaan Sektor Property dan Real Estate Di Bei. BMAJ: Business Management Analysis Journal, 1(1), 49-59. https://doi.org/10.24176/bmaj.v1i1.2682

Tamrin, M., Mus, H. R., \& Arfah, A. (2017). Effect of Profitability and Dividend Policy on Corporate Governance and Firm Value: Evidence From the Indonesian Manufacturing Sectors. Journal of Business and Management, 19(10), 66-74. https://doi.org/10.31219/osf.io/7m9uk

Tantawi, D., \& Jonnardi. (2020). Pengaruh Likuiditas, Firm Growth, Leverage dan Profitabilitas terhadap Nilai Perusahaan. Jurnal Multiparadigma Akuntansi Tarumanagara, 2(4), 1460-1468.

Verdian, \& Ispriyahadi, H. (2020). Danlikuiditas terhadap Nilai Perusahaan Properti dan Real Estate (Studi Empiris pada Perusahaan Properti dan Real Estate yang Terdaftar di Bursa Efek Indonesia Tahun 2010-2016). Jurnal Ekobis: EKonomi Bisnis dan Manajemen, 10(2), 119-133.

Vernando, J., \& Erawati, T. (2020). Pengaruh Ukuran Perusahaan terhadap Nilai Perusahaan dengan Struktur Modal sebagai Variabel Intervening: Studi Empiris di BEI. Jurnal Riset Manajemen dan Bisnis, 15(1), 13-25.

Wiagustini, N. L. P. (2010). Dasar-Dasar Keuangan Manajemen (J. Atmaja (ed.)). Bali: Udayana University Press.

Wongso, A. (2013). Pengaruh Kebijakan Dividen, Struktur Kepemilikan, dan Kebijakan Hutang terhadap Nilai Perusahaan dalam Perspektif Teori Agensi dan Teori Agensi dan Teori Signaling. Jurnal Ilmiah Mahasiswa Manajemen, 1(5), 1-6.

Wulandari, D. R. (2013). Pengaruh Profitabilitas, Operating Leverage, Likuiditas terhadap Nilai Perusahaan dengan Struktur Modal Sebagai Intervening. Accounting Analysis Journal, 2(4), 455-463. https://doi.org/10.15294/aaj.v2i4.4172 